\title{
A Survey on Chemical Hazards and Liver Function in Rubber Industry Workers in Iran
}

\author{
Ehsan Rafeemanesh, Mojtaba Mousavi Bazzaz, Farhoud Sadrossadat, \\ Fatemeh Ahmadi* \\ Faculty of Medicine, Mashhad University of Medical Sciences, Mashhad, Iran \\ Email: ${ }^{*}$ Ahmadif911@mums.ac.ir
}

Received 5 April 2015; accepted 19 May 2015; published 22 May 2015

Copyright (C) 2015 by authors and Scientific Research Publishing Inc.

This work is licensed under the Creative Commons Attribution International License (CC BY).

http://creativecommons.org/licenses/by/4.0/

(c) $\underset{\mathrm{EY}}{\mathrm{B}}$ Open Access

\section{Abstract}

Rubber industries workers are at risk of hepatic dysfunction from exposure to rubber dust and a mixture of different hydrocarbons. This study aimed to evaluate the relation between chemical hazards in workplace and serum hepatic transaminases in rubber industry workers in Iran. This historical cohort study was conducted in a rubber-manufacturing industry in Mashhad. It consisted of 91 workers with chemical substances exposure and 85 workers not exposed to chemicals. Hepatic transaminases including alanine transaminase (ALT) and aspartate transaminase (AST) were compared between these two groups. Required data were collected through questionnaire, liver enzymes evaluation, and environmental monitoring of chemical substances. The data were analyzed with SPSS 11.5. A total of 176 workers enrolled in this study included $113(64.2 \%)$ male and $73(35.8 \%)$ female. The mean of age and employment duration in exposed group were $29.22 \pm$ 3.99 and $5.41 \pm 2.77$ and in non-exposed group were $30.33 \pm 4.11$ and $5.29 \pm 2.77$ respectively. The mean of ALT in exposed and non-exposed groups was $31.3 \pm 8.04$ and $23.8 \pm 10.42(p=0.01)$ and the mean of AST was $29.6 \pm 9.7$ and $27.3 \pm 8.2(p=0.1)$ respectively. A significant difference was shown between mean of ALT at the date of employment and at the time of the study in exposed group. According to our findings evaluation of serum transaminases is a useful screening method which might be beneficial in early detection of hepatocellular injuries in rubber industry workers.

\section{Keywords}

Chemical Substances, Transaminases, Liver Dysfunction, Rubber Industry

\footnotetext{
"Corresponding author.
} 


\section{Introduction}

Liver is the main organ responsible for drugs and toxic chemicals metabolism, so it is the primary target organ for many organic solvents. Some studies suggest that organic solvents can lead to liver toxicity. Presently, organic solvents are widely used in different industries including printing, paint and adhesives industries, rubber production, photographic films and toy manufacturing [1]. Although a number of industrial products are recognized as hepatotoxic agents, liver disease associated with occupational exposure is less noticed and diagnosed [2]. Various factors are involved in liver toxicity such as age, ethnicity, genetic factors, nutritional status, alcohol and drugs. In one study neonatal rats were less sensitive to carbon tetrachloride and bromobenzene toxicity compared with adult animals [3].

Some occupational liver diseases can represent with acute symptoms such as exposure to carbon tetrachloride and chloroform that lead to severe liver toxicity, but others can reveal chronic manifestations such as prolonged exposure to aromatic and aliphatic solvents which can result in mild liver toxicity [4]-[6]. In the study of Malaguarnera, et al., some solvents including dimethylformamide (DMF), trichloroethylene (TCE), toluene, xylene, carbon tetrachloride, and chloroform were proposed as factors involved in hepatotoxicity [7]. Liver function indicators, alanine transaminase (ALT) aspartate transaminase (AST) and Gamma-glutamyltransferase (GGT) were also evaluated in 593 workers with low-level exposure to lead and organic solvents in another study. According to the results, AST and ALT levels were significantly higher in exposed group compared with nonexposed group [8]. Examining liver function tests in 89 workers of a paint industry exposed to organic solvents in South Africa showed that $65 \%$ of workers have at least one hepatic enzyme higher than the normal concentration rate; GGT was elevated in $46 \%$ of workers and AST in 52\% of workers. Comparing the exposure to different concentrations of organic solvents revealed that AST and GGT levels will be increased more by exposing to higher levels of solvents [9]. Broudkin, et al. showed a constant and linear relation between hepatic transaminases level and environmental styrene [10].

Organic solvents such as benzene, toluene and other hydrocarbons are chemical agents in forms of gases or vapors involved in rubber producing industries. Almost 200 chemical factors are used in rubber compound production; each one might be associated with specific adverse effects [6]. Although rubber industry associated diseases such as nervous, bladder and hematopoietic system diseases have been studied previously, there are not sufficient studies about liver toxicity and complications in rubber industries. The present study aimed to investigate the relation between chemical agent's exposure in one rubber production plant and increased level of liver enzymes in workers.

\section{Materials and Methods}

This historical cohort study was conducted in a rubber industry in 2013 in Mashhad, Iran. In this plant, rubber products were produced from rubber compound with extrusion and injection molding methods for automobile industry.

First, 100 workers of production department exposed to chemical agents and the same number of official members not exposed to chemicals were randomly selected. The inclusion criteria were at least one year working experience in this plant. Data about workers age, gender, weight and height, duration of employment, medical history, medication and alcohol consumption were obtained through questionnaire and workers medical documents. In our study we excluded the subjects with any alcohol consumption, medicine administration, regular smokers, abnormal liver function tests at the beginning of employment and previous diseases such as hepatitis, hyperthyroidism, celiac... based on their medical history and laboratory evaluations. Finally the total number of exposed and non-exposed groups was 96 and 89 workers respectively.

Venous Blood samples were collected to analyze the exact levels of ALT and AST. The blood samples were stored at $+4^{\circ} \mathrm{C}$ and carried out within $8 \mathrm{~h}$ of sampling to laboratory. The liver enzymes were determined by Pars-azmoon Company kits [Iran] and Hitachi Autoanalyzer 7050 [Japan]. Normal range of both ALT and AST was 14 - $40 \mathrm{U} / \mathrm{L}$.

Environmental sampling and analysis of airborne substances including total rubber particulates and organic solvents mixture was achieved by occupational hygienist according to the National Institute for occupational Safety and Health (NIOSH) Manual of Analytical Methods [11] [12]. The sampling was performed for 8-hour's shift with 0.5 liter per minute flow rate in different parts of production unit. The organic solvents collection was done by activated charcoal tubes, then sampling tubes were broken and the glass wool and foam discarded. For 
desorption, $1 \mathrm{ml}$ carbon disulfide was added and allowed to stand for 30 minutes with occasional agitation. Sample analysis was done by gas chromatography for solvents and gravimetric for particulates. Sample analysis were done by gas chromatography for solvents and gravimetric for particulates. The method of American Conference of Governmental Industrial Hygienist (ACGIH) was used to calculate the TLV of solvents mixture [13]:

$$
\operatorname{TLV}[\text { solvents mixture }]=\mathrm{C}_{1} / \mathrm{T}_{1}+\mathrm{C}_{2} / \mathrm{T}_{2}+\cdots \mathrm{C}_{\mathrm{n}} / \mathrm{T}_{\mathrm{n}}
$$

$\mathrm{C}=$ the measured concentration of particular substance

$\mathrm{T}=$ the national occupational exposure

Data are expressed as mean \pm SD. The t-test and analysis of variance were used to compare quantitative variables in exposed and non-exposed groups. Pair t-test was also used to compare the liver enzymes levels at the beginning of employment and the time of the study and chi-square test was performed to evaluate the qualitative variables. The data were analyzed with SPSS 11.5 . In all analysis $\mathrm{P} \leq 0.05$ was considered statistically significant.

The ethics committee of Mashhad University of Medical Sciences approved this study. All subjects signed informed consent forms before their inclusion in the study.

\section{Results}

From 176 workers entered this study, 113 (64.2\%) were male and 63 (35.8\%) were female. Two groups of study were similar in sex. The mean of age and employment duration were not significantly different between exposed and non-exposed groups $(\mathrm{P}=0.09, \mathrm{P}=0.7$ respectively). The average of body mass index (BMI) was 2.6 higher in non-exposed group compared with exposed group $(\mathrm{P}=0.008)$.

Although the average of AST was similar between two groups $(\mathrm{P}=0.1)$, the average of ALT level was significantly different while compared between exposed and non-exposed groups $(\mathrm{P}=0.01)$. Table 1 and Table 2 show the mean comparison of quantitative variables between the two groups in this study.

Based on workplace environmental assessments, a mixture of organic hydrocarbons including benzene, toluene and xylene and also rubber dusts were present at production unit. Although the exposure rate to each single chemical was within the permissible exposure limit, the mean of the exposure to the mixture of hydrocarbons was greater than the permissible exposure limit in some places include fluke room or adhesive cab. Table 3 shows the major chemical exposures in different parts of this industry.

Significant difference was observed in exposed group between the mean of ALT at the time of employment and at the time of performing the study but no significant difference was identified regarding the mean of AST in exposed group. Table 4 shows the comparison of the aminotransferases at the time of the study with pre-employment in production unit workers.

\begin{tabular}{cccc} 
Table 1. Comparison of demographic variables between the two groups. & \\
\hline & $\begin{array}{c}\text { Production Workers } \\
\text { Mean } \pm \text { SD } \\
\mathrm{N}=96\end{array}$ & $\begin{array}{c}\text { Office Workers } \\
\text { Mean } \pm \text { SD } \\
\mathrm{N}=89\end{array}$ & P-Value \\
\hline Variables & $29.22 \pm 3.99$ & $30.33 \pm 4.11$ & 0.09 \\
Age [years] & $5.41 \pm 2.77$ & $5.29 \pm 2.77$ & 0.7 \\
Work Experience [years] & $20.93 \pm 3.04$ & $23.57 \pm 3.35$ & $0.008^{*}$ \\
\hline BMI $\left[\mathrm{kg} / \mathrm{m}^{2}\right.$ ] & &
\end{tabular}

*Significant P-value.

Table 2. Comparison of transaminases between the two groups.

\begin{tabular}{cccc}
\hline Variables & $\begin{array}{c}\text { Production Workers } \\
\text { Mean } \pm \text { SD } \\
\mathrm{N}=96\end{array}$ & $\begin{array}{c}\text { Office Workers } \\
\text { Mean } \pm \text { SD } \\
\mathrm{N}=89\end{array}$ & P-Value \\
\hline AST [U/L] & $29.6 \pm 9.7$ & $27.3 \pm 8.2$ & 0.1 \\
ALT[U/L] & $31.3 \pm 8.04$ & $23.8 \pm 10.42$ & $0.01^{*}$ \\
\hline
\end{tabular}

*Significant P-value. 
Table 3. The major environmental Exposures in production workers (TWA).

\begin{tabular}{|c|c|c|c|c|}
\hline \multirow{2}{*}{ Variables } & \multicolumn{2}{|c|}{$\begin{array}{l}\text { Rubber Dust } \\
\mathrm{mg} / \mathrm{m}^{3}\end{array}$} & \multicolumn{2}{|c|}{$\begin{array}{c}\text { Organic Solvents } \\
\text { PPM }\end{array}$} \\
\hline & TWA & TLV & TWA & TLV \\
\hline Production Unit1 & 0.008 & $5 \mathrm{mg} / \mathrm{m}^{3}$ & 0 & - \\
\hline Production Unit 2 & 0.480 & $5 \mathrm{mg} / \mathrm{m}^{3}$ & 0 & - \\
\hline Production Unit 3 & 0.245 & $5 \mathrm{mg} / \mathrm{m}^{3}$ & 0 & - \\
\hline Assembly Unit 1 & 0.740 & $5 \mathrm{mg} / \mathrm{m}^{3}$ & 0 & - \\
\hline Assembly Unit 2 & 2.12 & $5 \mathrm{mg} / \mathrm{m}^{3}$ & 0 & - \\
\hline Assembly Unit 3 & 1.81 & $5 \mathrm{mg} / \mathrm{m}^{3}$ & 0 & - \\
\hline Adhesive Unit & 0 & - & $\begin{array}{c}\text { Benzene }=0.1 \\
\text { Xylene }=20 \\
\text { Toluene }=14\end{array}$ & $\begin{array}{c}0.5 \\
100 \\
20\end{array}$ \\
\hline Fluke Unit & 0 & - & $\begin{array}{c}\text { Benzene }=0.4 \\
\text { Xylene }=40\end{array}$ & $\begin{array}{c}0.5 \\
100\end{array}$ \\
\hline
\end{tabular}

Table 4. Comparison of the aminotransferases in time of study with pre-employment time in production workers.

\begin{tabular}{ccc}
\hline Variables & $\begin{array}{c}\text { ALT [U/L] } \\
\text { Mean } \pm \text { SD }\end{array}$ & $\begin{array}{c}\text { AST [U/L] } \\
\text { Mean } \pm \text { SD }\end{array}$ \\
\hline Time of Study & $31.3 \pm 8.04$ & $29.6 \pm 9.7$ \\
Pre Employment & $25.33 \pm 8.28$ & $28.29 \pm 6.94$ \\
P-Value & $0.04^{*}$ & 0.7 \\
\hline
\end{tabular}

${ }^{*}$ Significant P-value.

Pearson correlation analysis between age, work experience and BMI with transaminases in exposed and non-exposed groups didn’t show any significant correlation (Correlation $<1$ ).

\section{Discussion}

Rubber manufacturing involves different pollutants in common with plastic and paint producing industries including rubber dusts and mixture of organic hydrocarbons such as benzene, toluene, xylene, ethylene, propylene, and butadiene. According to our findings, ALT level not only showed significant difference in exposed and non-exposed groups, but also revealed significant difference at the time of employment and at the time of the study in exposed group workers. Some previous studies also showed significant association between chemical exposure in rubber industries and liver dysfunction. One study demonstrated 35\% increase of billirubin level in 526 rubber producing members [14]. In South Africa liver tests in 89 workers of paint industry exposed to organic solvents revealed increased level of at least one enzyme in $65 \%$ of evaluated workers; GGT in $46 \%$ and AST in 52\% workers. According to this study, workers with greater amount of solvents exposure reveal higher levels of AST and GGT [15]. Similar results were obtained in the study of Landberg, et al. by examining liver function in painters highly exposed to organic solvents. According to this study long term heavy exposure to solvents may elicit changes in conventional liver function tests indicative of a mild chronic effect on the liver. [16]. Hepatotoxicity has been also reported as a result of occupational exposure with organic solvents including toluene and xylene [17]. In 2004, significant relation has been proposed between increased levels of cholesterol and 5-year organic solvents exposure [18]. In 2006, petrochemical workers revealed considerable increase in their liver transaminases compared with non-exposed individuals [19]. Liver enzymes disorders were also identified among 150 refinery workers in a case-control study by Carvalho [20]. In a study by Dossing, et al., 3 chemical plant workers became jaundiced and showed hepatic necrosis due to occupational exposure to carbon 
disulphide, isopropanol, toluene, and acrylonitrile for 2 to 4 months [21]. According to the study of Liu,et al. direct association is detected between benzene, toluene, and xylene exposure with GGT and alkaline phosphatase (ALP) levels. Direct positive relation has been also detected by comparing dichlorobenzene and tetrachloroethane exposure with lactate dehydrogenase (LDH) and bilirubin levels [22]. Occupational exposure to organic solvents and lead resulted in increased levels of AST and ALT in another study [10].

Conversely, some investigations suggested no association between occupational exposures and liver function tests. In the study of Fernández-D’Pool, J. et al. liver transaminases and bile acids and urinary phenols concentration were not influenced by occupational exposure to solvents [23]. Similar results were obtained by investigating on car industry painters exposed to organic solvents in lower amounts of permissible level [24]. In 2003, weak effect of painting on normal liver function of painter is indicated by Goji, et al. [25].

In a similar study conducted in Iran, no significant changes have been shown in liver enzymes levels of painters following exposure to non-halogenated solvents [26]. Attarchi, et al. proposed no significant relation between transaminases level and exposure to a mixture of aromatic solvents; however alkaline phosphatase was changed statistically significant in automobile plant workers compared with non-exposed individuals [27]. According to mentioned studies, wide discrepancies observed among findings might be due to different methodology, sample size, type and intensity of occupational exposure, evaluated tests, and application of protective equipments.

The relation between liver enzymes and BMI is investigated in various studies. According to the study of Ruhl, et al., younger age, male sex, higher BMI, and cholesterol and glucose levels are among factors associated with increased levels of ALT. Based on their results, high BMI (BMI $\geq 25)$ accounts for $65 \%$ of individuals with elevated ALT level [28]. Similar results obtained in other studies regarding the risk of high BMI in elevating ALT [29] [30]. In the study of Adams et al. the risk of an elevated ALT was seven-fold higher with obesity [31].

In our study, confounding variables including age, sex, chronic liver diseases, alcohol consumption, medication and employment duration were adjusted between exposed and non-exposed groups.

Although the average of BMI was 2.6 higher in non-exposed group compared with exposed group, the effect of this factor could not be significant in our study because it was higher in non-exposed group and also there was no significant correlation between BMI and transaminases in exposed and non-exposed groups (correlation coefficient $=0.13$ and 0.8 with $\mathrm{P}_{\mathrm{AST}}=0.9, \mathrm{P}_{\mathrm{ALT}}=0.8$ ). The relation between liver enzymes and $\mathrm{BMI}$ is investigated in various studies. According to the study of Ruhl, et al., younger age, male sex, higher BMI, and cholesterol and glucose levels are among factors associated with increased levels of ALT. Based on their results, high BMI (BMI $\geq 25$ ) accounts for $65 \%$ of individuals with elevated ALT level [28]. Similar results obtained in other studies regarding the risk of high BMI in elevating ALT [29] [30]. In the study of Adams, et al. the risk of an elevated ALT was seven-fold higher with obesity [31].

Transaminases are known as sensitive indicators of liver injuries and hepatocellular diseases [32]. Due to the wide variety of liver functions, applying multiple screening tests for liver function will increase the sensitivity of hepatic injuries diagnosis. Serum bile acids measuring is a high-cost method that has some advantageous for liver disorders diagnosis.

However, there are some limitations in this study. First, this is a cross-sectionalstudy. Therefore, the causality can only be an assumption. Second, due to the facilities for changing and relocating the job or retirement of workers with occupational diseases, healthy worker effect may be existed. Conducting further studies specifically cohort studies with larger sample size are recommended for future.

\section{Conclusion}

This study indicates that exposure to rubber dust and mixture of hydrocarbons have effects on liver function, therefore evaluation of transaminases in rubber industry workers might be beneficial in early diagnosis of hepatocellular injuries. Where the risk of exposure to chemicals is found not acceptable, suitable control measures must be implemented to minimize the exposures. These control measures include substituting the hazardous substance with another substance which presents less, or no risk; engineering measures; safe work practices; administrative measures and personal protection.

\section{Acknowledgements}

The authors express their gratitude to the manager and staffs of HSE unit of Partlastic Complex for their sincere 
cooperation. This study was supported by the Vice Chancellor for Research of Mashhad University of Medical Sciences with approved number of 900632.

\section{References}

[1] Fiedler, N. and Lerman, S. (2007) Organic Solvents and Fuels. In: Rom, W.N., Ed., Occupational and Environmental Medicine, Lippincott Williams \& Wilkins, Philadelphia, 1102-1122.

[2] Dossing, M. (1986) Occupational Toxic Liver Damage. Journal of Hepatology, 3, 131-135.

[3] Mitchell, J.R., Jollow, D.J., Gillette, J.R. and Brodie, B.B. (1973) Drug Metabolism as a Cause of Drug Toxicity. Drug Metabolism and Disposition, 1, 418-423.

[4] Ladou, J. and Harrison, R. (2014) Occupational and Environmental Medicine. McGraw-Hill, Philadelphia.

[5] Johnson, D. and Groopman, J.D. (2007) Toxic Liver Disorders. In: Rom, W.N., Ed., Occupational and Environmental Medicine, Lippincott Williams \& Wilkins, Philadelphia, 792-799.

[6] Rosenstock, L., Cullen, M.R., Brodkin, C.V. and Redlich, C.A. (2005) Clinical Occupational and Environmental Medicine. W.B. Saunders, Philadelphia.

[7] Malaguarnera, G., Cataudella, E., Giordano, M., Nunnari, G., Chisari, G. and Malaguarnera, M. (2012) Toxic Hepatitis in Occupational Exposure to Solvents. World Journal of Gastroenterology, 18, 2756-2766. http://dx.doi.org/10.3748/wjg.v18.i22.2756

[8] Chang, W.J., Joe, K.T., Park, H.Y., Jeong, J.D. and Lee, D.H. (2013) The Relationship of Liver Function Tests to Mixed Exposure to Lead and Organic Solvents. Annals of Occupational and Environmental Medicine, 25, 5. http://dx.doi.org/10.1186/2052-4374-25-5

[9] Brautbar, N. and Williams, J. (2002) Industrial Solvents and Liver Toxicity: Risk Assessment, Risk Factors and Mechanisms. International Journal of Hygiene and Environmental Health, 205, 479-491. http://dx.doi.org/10.1078/1438-4639-00175

[10] Brodkin, C.A., Moon, J.D., Camp, J., Echeverria, D., Redich, C.A., Willson, R.A. and Checkoway, H. (2001) Serum Hepatic Biochemical Activity in Two Populations of Workers Exposed to Styrene. Occupational and Environmental Medicine, 58, 95-102. http://dx.doi.org/10.1136/oem.58.2.95

[11] National Institute for Occupational Safety and Health (2013) NIOSH Manual of Analytical Methods. http://www.cdc.gov/niosh/docs/2003-154/method-0500.html

[12] National Institute for Occupational Safety and Health (2013) NIOSH Manual of Analytical Methods. http://www.cdc.gov/niosh/docs/2003-154/method-2000.html

[13] Cohen, B. (2007) Industrial Hygiene Measurement and Control. In: Rom, W.N., Ed., Environmental and Occupational Medicine, Lippincott Williams \& Wilkins, Philadelphia, 1768.

[14] Katz, B. (1962) Toxicochemical Affection of the Liver with Styrene under Operating Conditions. Gigiena Truda, 10, 21-23.

[15] Rees, D., Soderlund, N., Cronje, R., Song, E., Kielkowski, D. and Myers J. (1993) Solvent Exposure, Alcohol Consumption and Liver Injury in Workers Manufacturing Paint. Scandinavian Journal of Work, Environment \& Health, 19, 236-244. http://dx.doi.org/10.5271/sjweh.1478

[16] Lundberg, I., Nise, G., Hedenborg, G., Hogberg, M. and Vesterberg, O. (1994) Liver Function Tests and Urinary Albumin in House Painters with Previous Heavy Exposure to Organic Solvents. Occupational and Environmental Medicine, 51, 347-353. http://dx.doi.org/10.1136/oem.51.5.347

[17] Nijem, K., Kristensen, P., Thorud, S., Al-Khatib, A., Takrori, F. and Bjertness, E. (2001) Solvent Exposures at Shoe Factories and Workshops in Hebron City. International Journal of Occupational and Environmental Health, 7, 182188. http://dx.doi.org/10.1179/oeh.2001.7.3.182

[18] Kaukianen, A., Vehmas, T., Rantala, K., Nurminen, M., Martikainen, R. and Taskinen, H. (2004) Results of Common Laboratory Tests in Solvent-Exposed Workers. International Archives of Occupational and Environmental Health, 77, 39-46. http://dx.doi.org/10.1007/s00420-003-0476-z

[19] Perez, C., Bosia, J., Cantore, M., Chiera, A., Cocozzella, D. and Adrover, R. (2006) Liver Damage in Workers Exposed to Hydrocarbons. Journal of Gastroenterology and Hepatology, 29, 334-337.

[20] Carvalho, F.M., Silvany Neto, A.M., Mendes, J.L., Cotrim, H.P., Nascimento, A.L., Lima Jr., A.S., et al. (2006) [Liver Enzyme Abnormalities among Oil Refinery Workers]. Revista de SaúdePública, 40, 92-98. http://dx.doi.org/10.1590/S0034-89102006000100015

[21] Døssing, M. and Ranek, L. (1984) Isolated Liver Damage in Chemical Workers. British Journal of Industrial Medicine, 41, 142-144. http://dx.doi.org/10.1136/oem.41.1.142 
[22] Liu, J., Drane, W., Liu, X. and Wu, T. (2009) Examination of the Relationships between Environmental Exposures to Volatile Organic Compounds and Biochemical Liver Tests: Application of Canonical Correlation Analysis. Environmental Research, 109, 193-199. http://dx.doi.org/10.1016/j.envres.2008.11.002

[23] Fernández-D’Pool, J. and Oroño-Osorio, A. (2001) Liver Function of Workers Occupationally Exposed to Mixed Organic Solvents in a Petrochemical Industry. Journal of Clinical Investigation, 42, 87-106.

[24] Kurppa, K. and Husman, K. (1982) Car Painters’ Exposure to a Mixture of Organic Solvents. Serum Activities of Liver Enzymes. Scandinavian Journal of Work, Environment \& Health, 8, 137-140. http://dx.doi.org/10.5271/sjweh.2491

[25] Goji, J., Tsuchiya, G., Fujita, D. and Koisomi, N. (2003) Effect of Painting Work on Alcoholic Liver Dysfunction. Sangyo Eiseigaku Zasshi, 45, 215-221. http://dx.doi.org/10.1539/sangyoeisei.45.215

[26] Aminian, O., Sharifian, A., Jalalie, M., Razi, M. and Ehsani Ardekani, M.J. (2007) Alterations of Hepatic Enzymes in Industrial Painters Exposed to Organic Solvents in Tehran. Journal of the Faculty of Medicine, 31, 279-283. (In Persian)

[27] Attarchi, M.S., AmiriRigi, A., Labbafinejad, Y. and Mohammadi, S. (2009) Effects of Occupational Exposure with Mixture of Aromatic Organic Solvents on Liver Enzymes in Workers of an Automobile Plant. Armaghane-Danesh Bimonthly Journal of Yasouj University of Medical Sciences, 14, 92-101. (In Persian)

[28] Ruhl, C.E. and Everhart, J.E. (2003) Determinants of the Association of Overweight with Elevated Serum Alanine Aminotransferase Activity in the United States. Gastroenterology, 124, 71-79. http://dx.doi.org/10.1053/gast.2003.50004

[29] Sull, J.W., Yun, J.E., Lee, S.Y., Ohrr, H., Jee, S.H., Guallar, E. and Samet, J.M. (2009) Body Mass Index and Serum Aminotransferase Levels in Korean Men and Women. Journal of Clinical Gastroenterology, 43, 869-875. http://dx.doi.org/10.1097/MCG.0b013e3181945956

[30] Lee, D.H., Ha, M.H. and Christiani, D.C. (2001) Body Weight, Alcohol Consumption and Liver Enzyme Activity-A 4-Year Follow-Up Study. International Journal of Epidemiology, 30, 766-770. http://dx.doi.org/10.1093/ije/30.4.766

[31] Adams, L.A., Knuiman, M.W., Divitini, M.L. and Olynyk, J.K. (2008) Body Mass Index Is a Stronger Predictor of Alanine Aminotransaminase Levels than Alcohol Consumption. Journal of Gastroenterology and Hepatology, 23, 1089-1093. http://dx.doi.org/10.1111/j.1440-1746.2008.05451.x

[32] Longo, D., Fauci, A., Kasper, D., Hauser, S., Jameson, L. and Loscalzo, J. (2012) Harrison’s Principal of Internal Medicine. McGraw-Hill, New York. 